\title{
Degradation of Toxic Indigo Carmine Dye by Electrosynthesized Ferrate (VI)
}

\author{
S. Barisci", H. Inan, O. Turkay, A. Dimoglo and D. Erol
}

Gebze Technical University, Environmental Engineering Department, 41400, Gebze, Kocaeli, Turkey

\begin{abstract}
Response surface methodology was applied for optimizing indigo carmine (IC) dye removal by electrochemically produced ferrate $(\mathrm{VI})$. Box-Behnken design was employed in this study, and design parameters were $\mathrm{pH}, \mathrm{Fe}(\mathrm{VI})$ dose and initial dye concentration $\left(\mathrm{C}_{0}\right)$. $\mathrm{R}^{2}$ and adjusted $\mathrm{R}^{2}$ values were very high that indicated very good accuracy for the employed model. Optimum operational conditions were: $4.08-7.69$ for $\mathrm{pH}, 24-118.83 \mathrm{mg} / \mathrm{L}$ for $\mathrm{Fe}(\mathrm{VI})$ dose and 60.68-99.13 mg/L for complete removal of IC. Produced by electrochemical method Ferrate (VI) provides high effectiveness for IC dye-containing synthetic wastewater.
\end{abstract}

Keywords: Box-Behnken design, Ferrate (VI), Indigo carmine, Response surface methodology.

\section{INTRODUCTION}

Textile industries consume large amount of fresh water during its unit processes and the water is contaminated by toxic chemicals. Especially, dyeing process during manufacturing facilities has the biggest risk to the environment due to high concentrations [1]. Discharging this type of wastewater directly into the surface waters causes negative effects on the flora and fauna.

Dyes have been commonly used in textile, paper and pulp, dyeing, tannery, printing, photographic, and coating industries. Frequently, the dye wastewaters cover dye pigments, non-biodegradable organic and inorganic substances. When dye wastewaters are discharged to the aquatic bodies, they hinder the biological processes such as photosynthesis, blocking light penetration in the water of lakes and rivers [2].

Indigo carmine (IC) is a fairly toxic dye which is used primarily in the production of denim textile. The contact with indigo may cause some irritations on skin and eye. Also it can cause harm to cornea and conjunctiva. It is known that IC dye is cancer-causing chemical and can cause acute toxicity. It has also been proved that the dye causes tumour when it is consumed [3]. For those reasons, release of IC without any treatment into the aquatic bodies is harmful and causes such diseases. However, since IC has symmetrical structure and strong stability, it is difficult to be degraded. Thus, recent researches take cognizance of the removal of IC dye-containing wastewaters. The technologies used for the

*Correspondence Address to this author at the Gebze Technical University, Environmental Engineering Department, 41400, Gebze, Kocaeli, Turkey; Tel: +902626053208; Fax: +902626053145; E-mail: sbarisci@gtu.edu.tr degradation of IC and other dyes consist of adsorption [4-8], aerobic bioreactors [9] and advanced oxidation processes such as electrooxidation [10-12], photocatalysis [13-21] and electrocoagulation [2, 22]. Although those methods seem to be efficient technologies, physical adsorption and coagulation transfer the contaminants from wastewater to other environment which resulted sludge production and advanced oxidation processes are expensive technologies. Additionally, dye wastewater requires treatment with new techniques due to its high concentration of organic compounds and toxicity. Ferrate $(\mathrm{VI})$ is capable of decomposing many toxic dyes to low-toxic products, and also of disinfecting wastewater. Its application is effective even by very low $(0.005-0.04 \mathrm{mg} / \mathrm{L})$ doses of ferrate $(\mathrm{VI})$. Unlike dry salts, the ferrate $(\mathrm{VI})$ solution is not stable. Ferrate $(\mathrm{VI})$ is expensive chemical, when a multi-stage synthesis is used to obtain them. All these disadvantages can be overcome when preparing ferrate (VI) by electrochemical method [23-25]. So that electrosynthesized ferrate $(\mathrm{VI})$ is a promising technology for the treatment of water and wastewater due to its high oxidizing power and coagulant effect. These properties make ferrate $(\mathrm{VI})$ very effective during the degradation processes. Ferrate (VI) can provide high degradation efficiency or it provides complete mineralization of contaminants without producing toxic by-products [26-32].

Response surface methodology (RSM) is a group of mathematical and statistical methods used for the optimization of output variables which are affected by many input factors [33]. It can be also used for the evaluation of interaction between individual variables. Recent studies have shown that RSM could be useful for the optimization of factors influenced on the processes [34-36]. RSM has been applied effectively 
for the removal of many pollutants by advanced oxidation processes [37-40].

In this study, degradation of highly toxic IC dye by electrochemically produced ferrate (VI) ion was investigated. RSM was used for optimization of the process according to color and chemical oxygen demand (COD) removal efficiencies relative to the key parameters, such as initial dye concentration, $\mathrm{pH}$ and ferrate (VI) dose.

\section{MATERIALS AND METHODS}

\subsection{Chemicals}

IC (dye content 95\%) and sodium hydroxide (anhydrous pellets and with 98\% purity) were supplied from Sigma-Aldrich. Buffers were used to adjust $\mathrm{pH}$ values: $\mathrm{C}_{8} \mathrm{H}_{5} \mathrm{KO}_{4}-\mathrm{HCl}$ solution $(\mathrm{pH} 4) ; \mathrm{KH}_{2} \mathrm{PO}_{4}-\mathrm{NaOH}$ solution ( $\mathrm{pH} 7$ ); $\mathrm{Na}_{2} \mathrm{~B}_{4} \mathrm{O}_{7} .10 \mathrm{H}_{2} \mathrm{O}-\mathrm{NaOH}$ solution $(\mathrm{pH}$ 10). Indigo dye containing synthetic wastewater was prepared as follows: $150 \mathrm{mg}$ IC dye was added to $1 \%$ $\mathrm{NaOH}$ solution and $5 \%$ sodium thiosulfate solution mixture and completed to $1000 \mathrm{ml}$. Initial COD value of the prepared solution was $320 \mathrm{mg} / \mathrm{L}$ and initial color value was 130 pt-co.

\subsection{Electrolytic System and Experimental Procedures}

In our study, ferrate (VI) synthesis was conducted in an electrolysis cell made of plexiglass material with the dimensions of $12 \times 7 \times 5 \mathrm{~cm}$. Electrodes were high purity iron plates with the dimensions of $10 \times 5 \times 0.2 \mathrm{~cm}$. Active electrode surface area was $156 \mathrm{~cm}^{2}$. NaOH was used to provide highly alkaline media. Current was supplied by DC power source. Details for optimal conditions of ferrate (VI) synthesis and its stability report can be found in our previous study [41]. All experiments were conducted using Box-Behnken experimental design: different ferrate (VI) doses (24, 72 and $100 \mathrm{mg} / \mathrm{L}$ as $\mathrm{Fe}$ $(\mathrm{VI})$ ), initial dye concentrations $(20,60$ and $120 \mathrm{mg} / \mathrm{L})$ and $\mathrm{pH}$ values (4, 7 and 10). After synthesis of ferrate (VI), desired amount of ferrate (VI) was dosed to indigo containing solution, and then $\mathrm{pH}$ was adjusted to the mentioned values with the buffer solutions: $\mathrm{C}_{8} \mathrm{H}_{5} \mathrm{KO}_{4}-$ $\mathrm{HCl}$ solution $(\mathrm{pH} 4) ; \mathrm{KH}_{2} \mathrm{PO}_{4}-\mathrm{NaOH}$ solution $(\mathrm{pH} 7)$; $\mathrm{Na}_{2} \mathrm{~B}_{4} \mathrm{O}_{7} \cdot 10 \mathrm{H}_{2} \mathrm{O}-\mathrm{NaOH}$ solution ( $\mathrm{pH} 9$ ). The initial $\mathrm{pH}$ of the IC solution was $11.5 \pm 0.2$. Rapid and slow mixing was applied for 30 seconds and 20 minutes, respectively. After mixing procedure, sedimentation took placed for one hour in the process. The supernatant was taken from the treated solution and all samples were filtered through $0.45 \mu \mathrm{m}$ membrane filters for the COD and color measurements. All experiments were performed at the room temperature.

\subsection{Analytical Methods}

COD was determined according to Standard Methods. Color was measured via $\mathrm{HACH}$ Lange DR 2800 spectrophotometer. Ferrate (VI) concentration was measured by $\mathrm{HACH}$ Lange DR 5000 UV-VIS spectrophotometer at a pre-determined wave length of $505 \mathrm{~nm}$.

\subsection{Mathematical and Statistical Procedures}

In this study, the design of experiments was prepared using Box-Behnken model and three input factors were selected $(\mathrm{A}: \mathrm{pH}, \mathrm{B}$ : $\mathrm{Fe}(\mathrm{VI})$ dose, $\mathrm{C}$ : initial dye concentration) for the optimization of indigo dye degradation by ferrate (VI) ion according to the two different responses $\left(R_{1}\right.$, color removal and $R_{2}, C O D$ removal).

The removal efficiencies were fitted to a general function indicating the interaction between dependent and independent variables using second-order polynomial equation. The employed model of the second order polynomial is:

$R=\beta_{o}+\sum \beta_{i} X_{i}+\sum \beta_{i i} X_{i}^{2}+\sum \beta_{i j} X_{i} X_{j}$

Where $R$ is the response which is predicted by the model, $X_{i}$ and $X_{j}$ are independent input factors, $\beta_{o}$ is the intercept, $\beta_{i}$ is a linear coefficient, $\beta_{i i}$ is a quadratic coefficient and $\beta_{i j}$ is the interaction coefficient.

To determine the influence of selected parameters on the process efficiency for indigo dye removal, different levels were chosen for each parameter. The selection of operating levels is summarized in Table S1.

Design expert, version 8.0.4.1 (STAT-EASE Inc., Minneapolis, USA) was used for the preparation of experimental design and the analysis of obtained data. The analysis of variance (ANOVA) was run for prediction of the statistical parameters.

\section{RESULTS AND DISCUSSION}

\subsection{Design of Experiments and ANOVA Report}

Table 1 shows the summary of experimental planning and each response from the point of the efficiencies on color and COD removal. 
Table 1: Experimental Plan for Box-Behnken Design and Responses in each Experiment

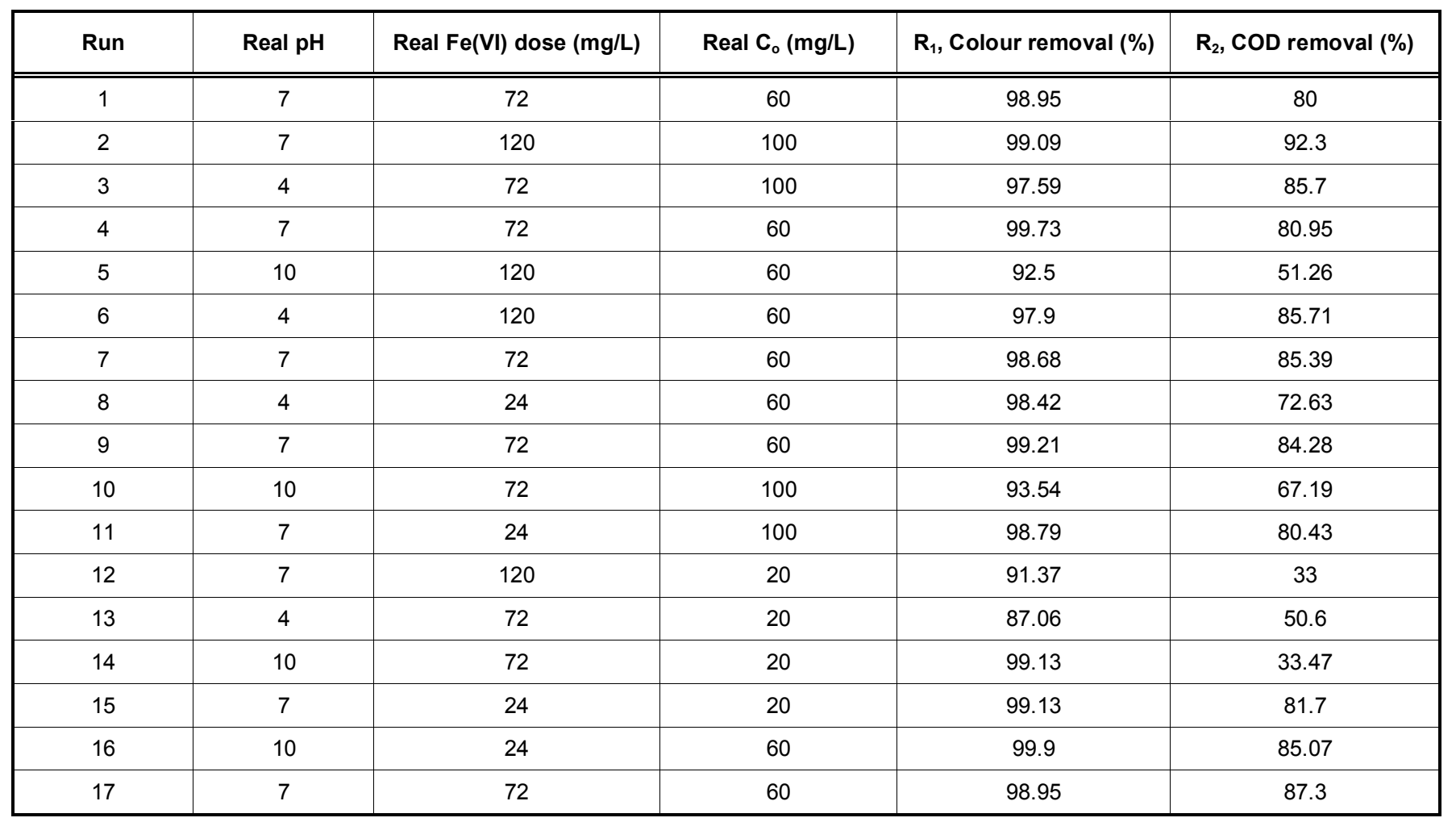

The ANOVA analysis indicates the significance of each parameter and also significance of the interaction between variables. ANOVA results can be seen in Table 2.
Probability value (Prob>F), F-value (Fisher variation ratio) of the model and adequate precision are the main points presenting the significance and acceptability of the model employed in the study. According to the

Table 2: ANOVA Results for Response Surface Quadratic Model

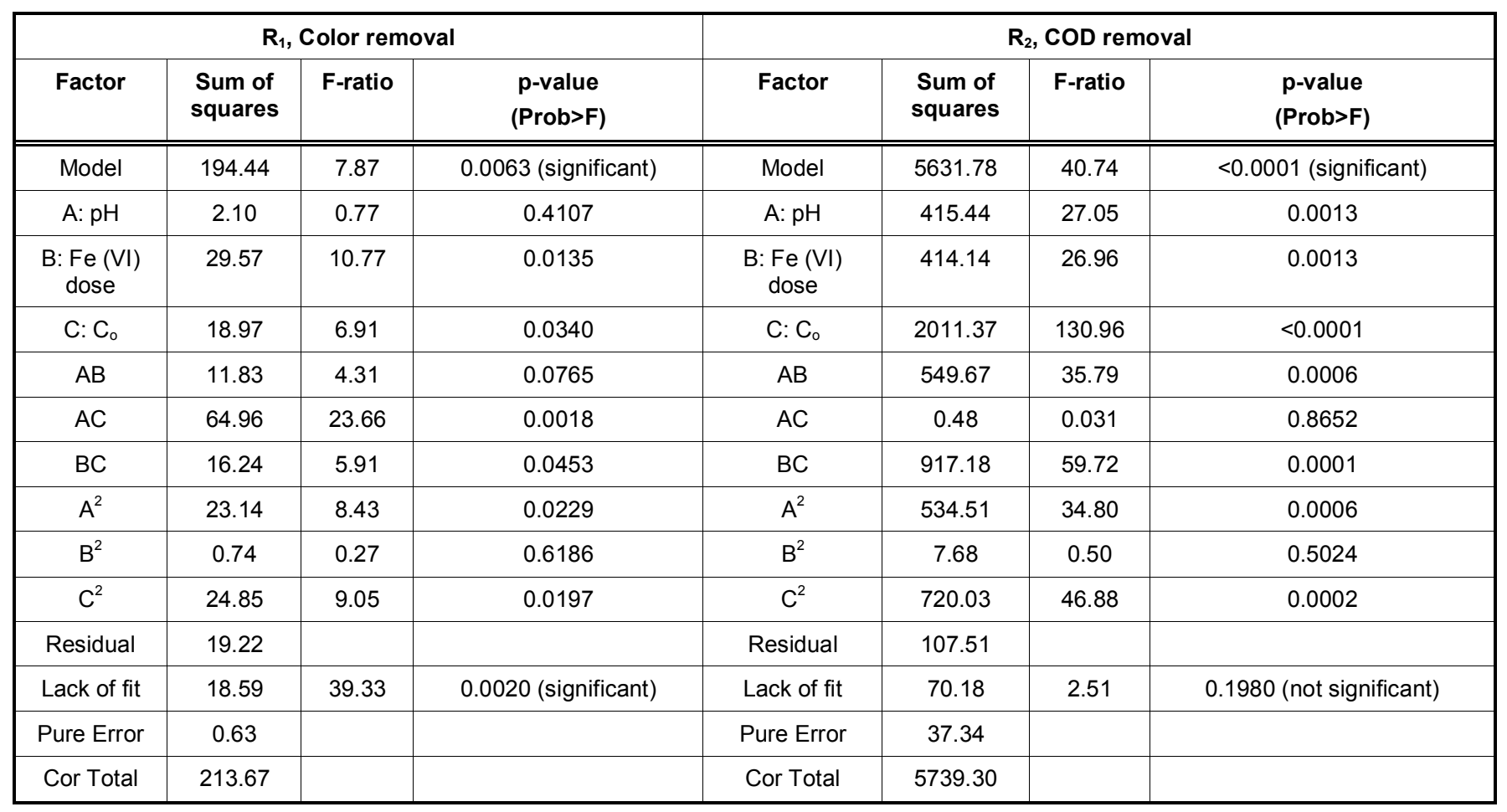


Table 3: ANOVA Results of the Polynomial Regression Model Established for Oxidation of Indigo Dye by Electrosynthesized Fe (VI)

\begin{tabular}{|c|c|c|}
\hline Parameter & $\mathbf{R}_{\mathbf{1}}$, Colour removal (\%) & $\mathbf{R}_{\mathbf{2}}$, CoD removal (\%) \\
\hline \hline $\mathrm{R}^{2}$ & 0.91 & 0.9813 \\
\hline Adjusted $\mathrm{R}^{2}$ & 0.7944 & 0.9572 \\
\hline Prob > F & 0.0063 & $<0.0001$ \\
\hline Model F value & 7.87 & 40.74 \\
\hline Std. Deviation & 1.66 & 3.92 \\
\hline PRESS & 298.44 & 1181.16 \\
\hline Adequate precision & 10.298 & 20.626 \\
\hline
\end{tabular}

ANOVA report, the model F-values of 7.87 and 40.74 imply the model's significance, and values of "Prob > $F$ " less than 0.0500 specify that the terms of the model are significant. In our case; $B, C, A C, B C, A^{2}$ and $C^{2}$ for color removal and $A, B, C, A B, B C, A^{2}$, and $C^{2}$ for $C O D$ removal are significant terms of the model (see Table 2).

The correlation factors $R^{2}$ are equal to 0.9813 and 0.91 for COD and color removal, as seen in Table 3. Model parameters for two responses (color and COD removal) are summarized, as well (see Table 2). High $\mathrm{R}^{2}$ values state that the total variation could be depicted by the model established in the present study phrasing a sufficient quadratic fit.

When second order polynomial model is considered (eq. 1), following expressions were obtained according to RSM:

Color removal $(\%)=99.28-1.92 \times B+1.54 \times C-$ $4.03 \times A x C+2.01 \times B x C-2.32 x A^{2}-2.41 x C^{2}$

COD removal $(\%)=78.37-7.21 \times A-7.20 \times B+15.86 \times C$ $-11.72 \times A x B+15.14 \times B \times C-11.27 \times A^{2}$

Where $\mathrm{A}$ is $\mathrm{pH}, \mathrm{B}$ is $\mathrm{Fe}(\mathrm{VI})$ dose and $\mathrm{C}$ shows initial dye concentration.

\subsection{Graphical Elucidation of the Model}

\subsubsection{Color Removal Efficiency}

Experimental results fitted the employed model with high $R^{2}$ value and were close to predicted values. They indicate that $R^{2}$ and adjusted $R^{2}$ values for the model is satisfactory (see Figure $\mathrm{S} 1$ in supplementary materials).

Figure 1 demonstrates the effect of different factors on the process in terms of color removal efficiency. As seen in Figure 1, color removal efficiency increased after $\mathrm{pH}$ value $(\mathrm{A})$ had become closer to the reference point $(0)$. Then the efficiency decreased, while the $\mathrm{pH}$ value became distant from the reference point. This situation indicates that the efficiency increases from acidic values through neutral values of $\mathrm{pH}$, and then color removal efficiency decreases with increasing $\mathrm{pH}$. The range of applied $\mathrm{Fe}$ (VI) doses (B) supplied efficient removal in color, as the efficiency was above $95 \%$ for all doses. The change of $\mathrm{Fe}(\mathrm{VI})$ dose between selected ranges seemed not providing accurate difference on color removal.

The effect of initial dye concentration (C) can be seen in Figure 1. According to Figure 1, color removal efficiency increased with increase of initial dye concentration until the reference point, and there was slight increase after reference point, too. But further increase of initial dye concentration until the maximum point $(+1)$ caused decrease in color removal efficiency. This means, that the efficiency increases with increasing dye concentration until certain point, only.

Figure 2 shows 3D graphics of the model. The effect of $\mathrm{Fe}(\mathrm{VI})$ dose on color removal efficiency at a constant initial dye concentration of $60 \mathrm{mg} / \mathrm{L}$ for different $\mathrm{pH}$ values was predicted. Color removal efficiency showed an increment with regard to increasing $\mathrm{pH}$ up to neutral values, and then the efficiency displayed decreasing trend in alkaline values. $\mathrm{Fe}(\mathrm{VI})$ dose role in color removal was insignificant, as far as high color removal efficiencies (>95\%) were obtained in all applied Fe (VI) doses, as seen in Figure 2a.

Figure $\mathbf{2 b}$ illustrates the interaction between color removal efficiency and initial dye concentration for different $\mathrm{pH}$ conditions at constant $\mathrm{Fe}(\mathrm{VI})$ dose (72 $\mathrm{mg} / \mathrm{L})$. The presence of higher dye concentrations, 


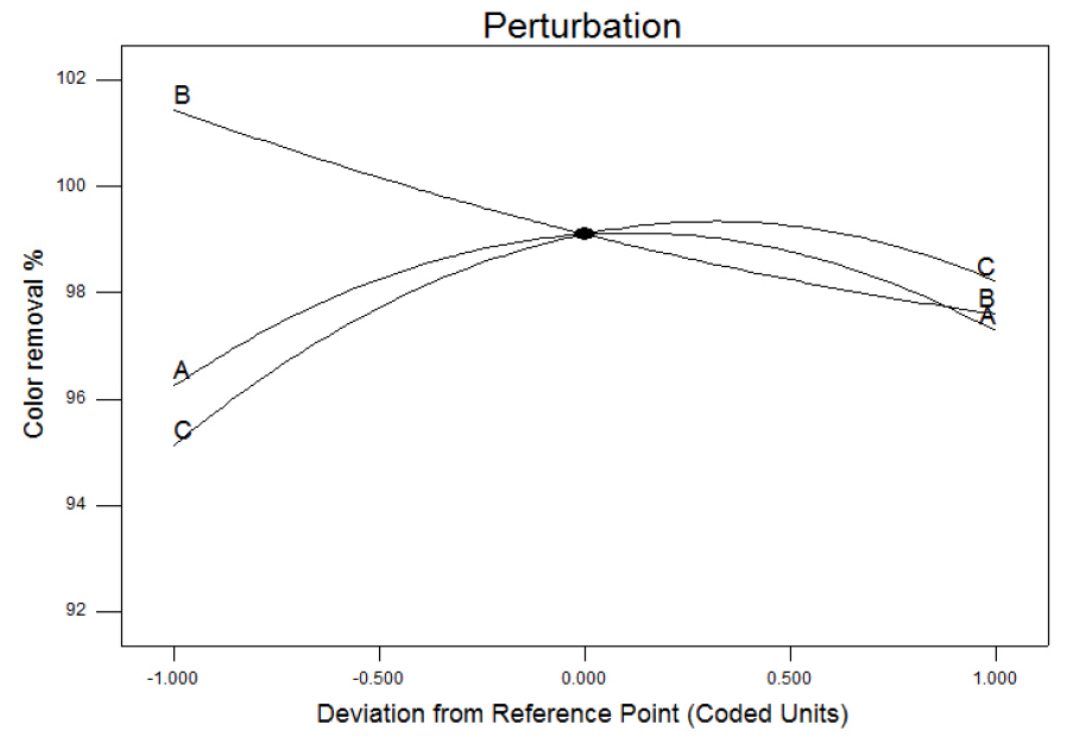

Figure 1: Perturbation plot for colour removal.

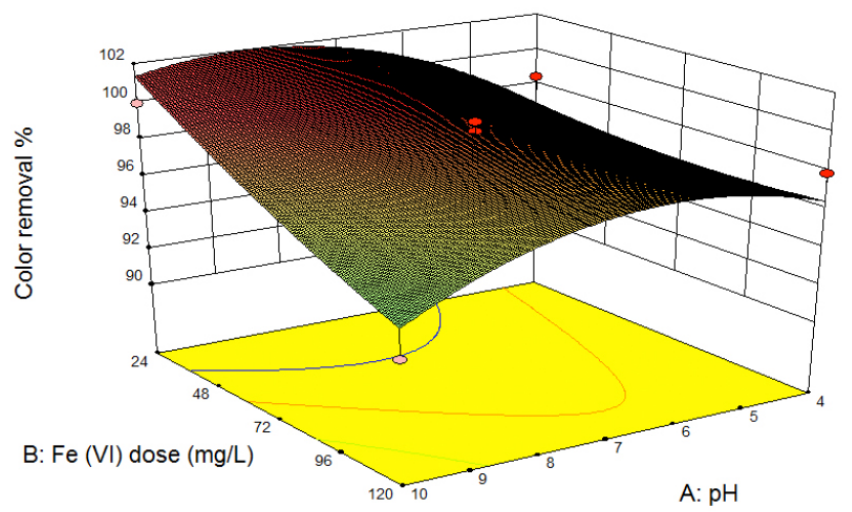

(a)

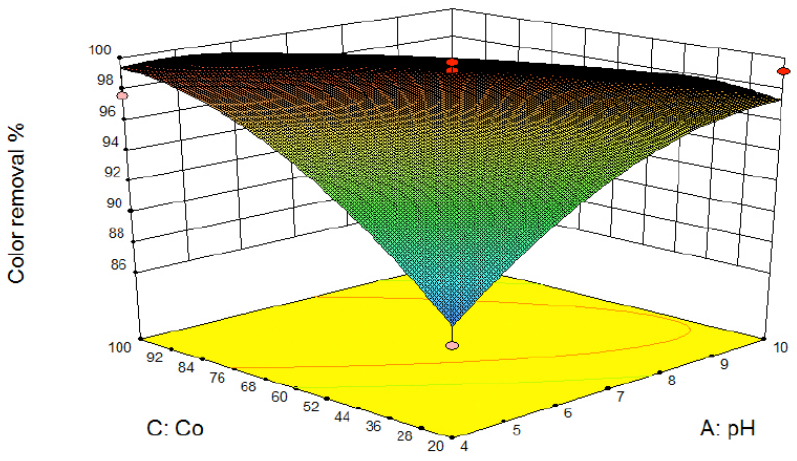

(b)

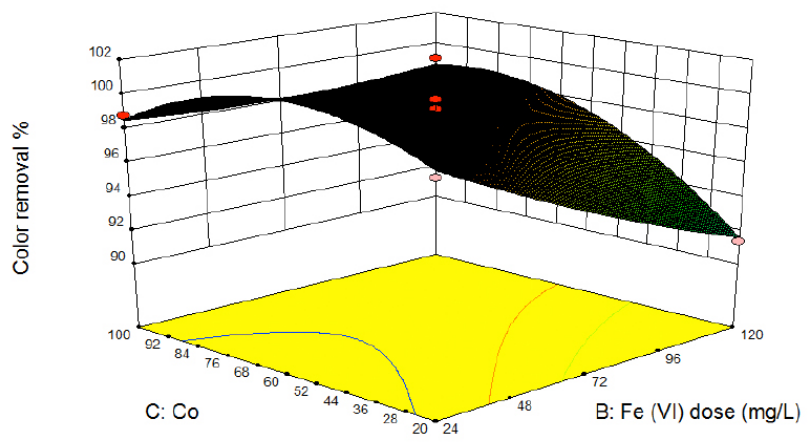

(c)

Figure 2: 3D surface plot for colour removal as a function of (a) $\mathrm{Fe}(\mathrm{VI})$ dose and $\mathrm{pH}$; (b) initial dye concentration and $\mathrm{pH}$ and (c) initial dye concentration and $\mathrm{pH}$.

together with neutral and alkaline conditions, was found to be more desirable for the indigo dye removal.

Figure $2 \mathrm{c}$ shows the interaction between initial dye concentration and $\mathrm{Fe}(\mathrm{VI})$ dose at $\mathrm{pH}$ 7. Lower Fe (VI) doses and higher dye concentrations showed higher color removal efficiency (>98\%).

\subsubsection{COD Removal Efficiency}

According to Figure 3, COD removal efficiency did not change by the variation of $\mathrm{Fe}(\mathrm{VI})$ dose as much as $\mathrm{pH}$ and initial dye concentration. The same behaviour with color removal was observed on COD removal. When $\mathrm{pH}$ value $(\mathrm{A})$ became closer to reference point, 


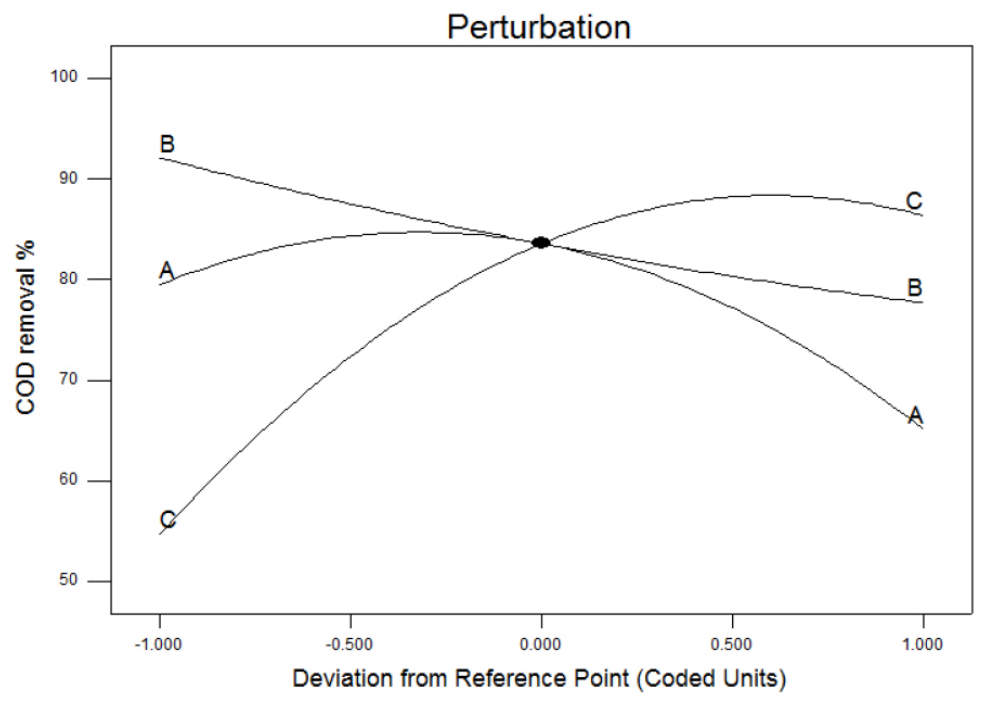

Figure 3: Perturbation plot for COD removal.

COD removal increased, but the efficiency started to decrease, when $\mathrm{pH}$ value became distant from reference point (0). Initial dye concentration affected COD removal more than color removal, as the change of efficiency was between $55-85 \%$. However, the trend was almost the same with color removal. While initial dye concentration was getting closer to the reference point, the efficiency was increasing. In contrast to color removal (Figure 1), the efficiency continued to increase after reference point for a while and then decreased until the maximum point.

As it can be shown in Figure 4a, the response was plain surface, which implies that there is no such

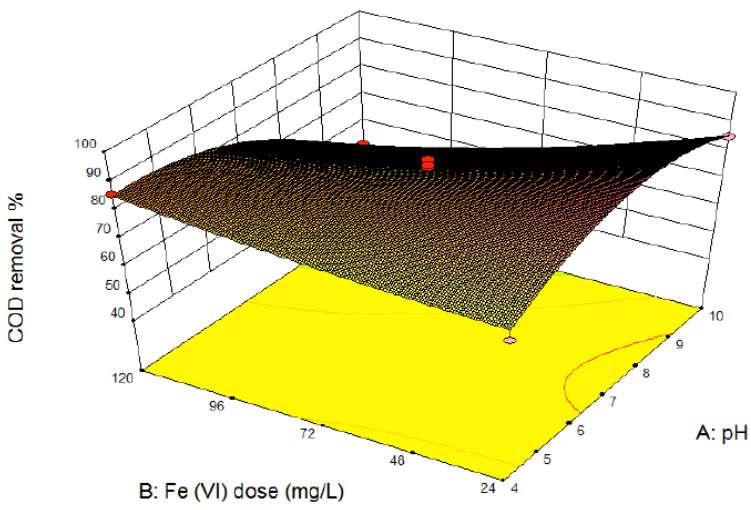

(a)

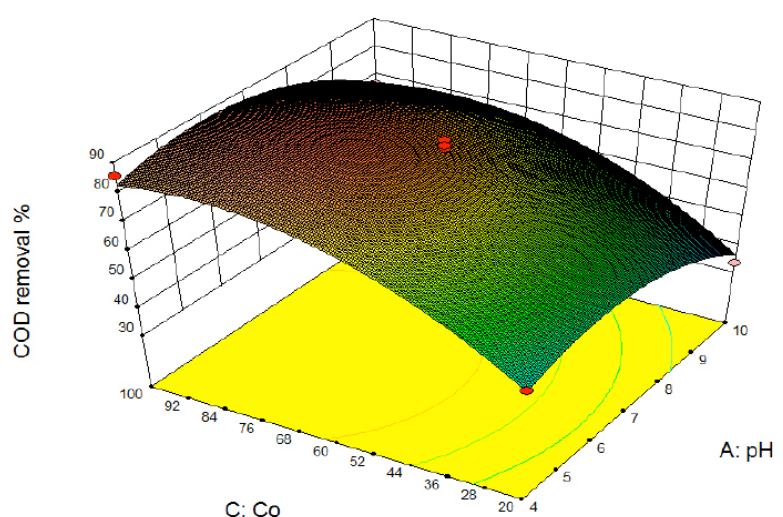

(b)

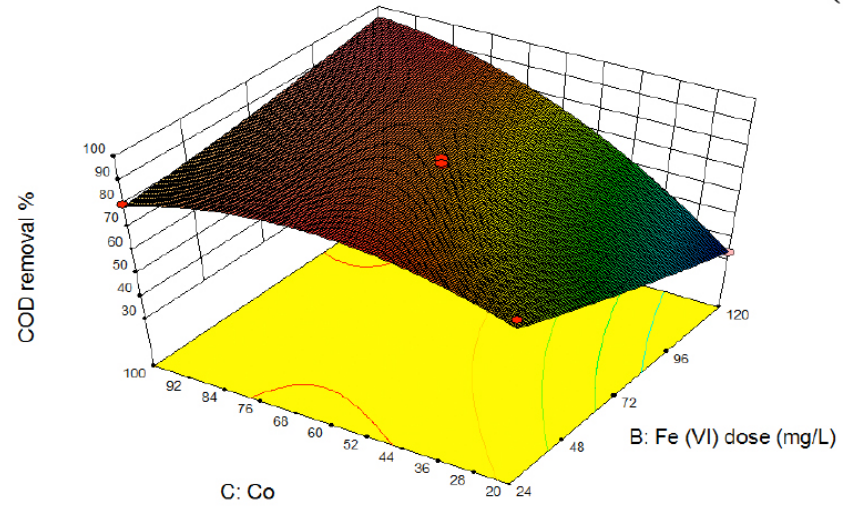

(c)

Figure 4: 3D surface plot for COD removal as a function of $(\mathbf{a}) \mathrm{Fe}(\mathrm{VI})$ dose and $\mathrm{pH}$; $(\mathbf{b})$ initial dye concentration and $\mathrm{pH}$ and $(\mathbf{c})$ initial dye concentration and $\mathrm{pH}$. 


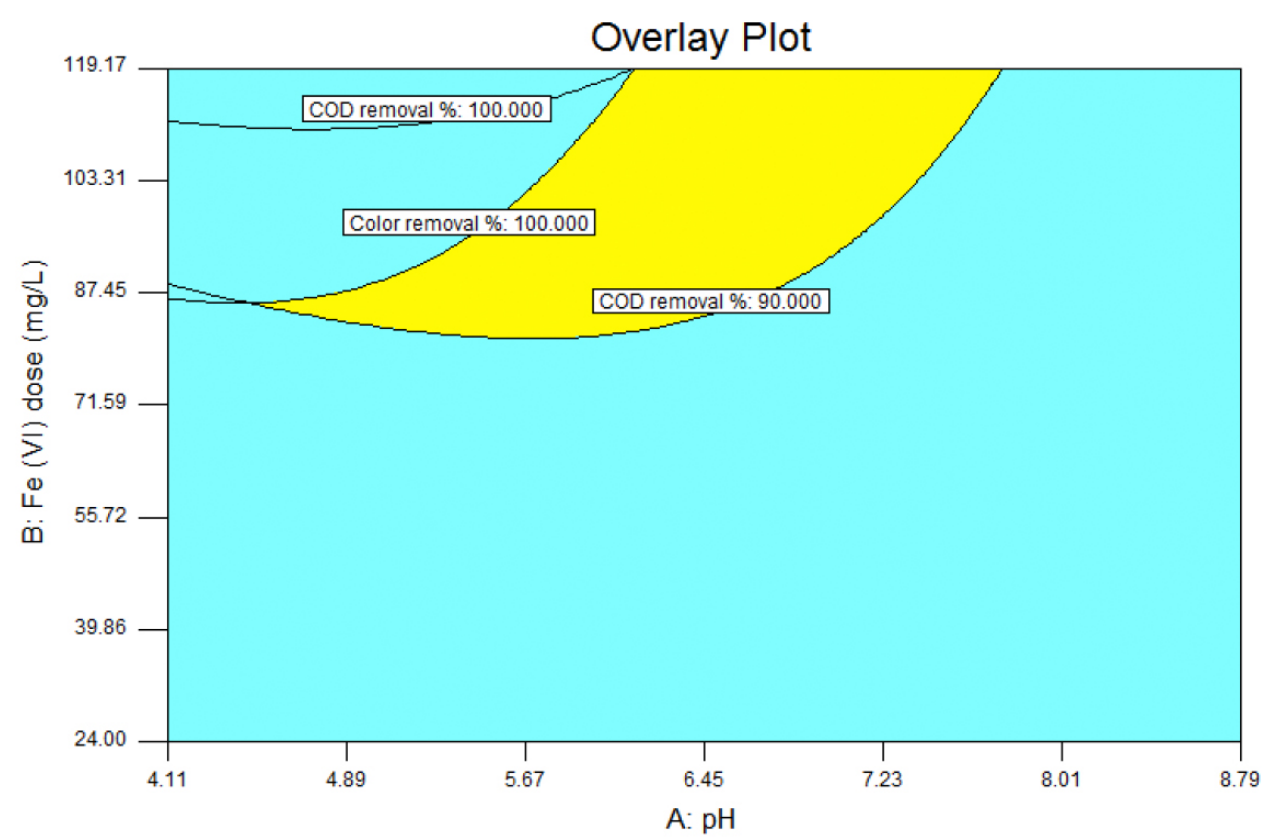

Figure 5: Overlay plot for the optimal region.

interaction between these variables $(\mathrm{Fe}(\mathrm{VI})$ dose and $\mathrm{pH}$ ) on the removal of COD. The change of $\mathrm{pH}$ had a dominant effect, compared to $\mathrm{Fe}(\mathrm{VI})$ dose, on the removal efficiency, as the slope was due to $\mathrm{pH}$ change, while $\mathrm{Fe}(\mathrm{VI})$ dose affected the process slightly.

In Figure 4b, 3D graphic of the model was convex surface, and maximum COD removal efficiency was obtained in the final region of initial dye concentration for the studied values. Through the neutral $\mathrm{pH}$ values, the removal efficiency increased, and after the neutral values there was a decrease through the final region of studied $\mathrm{pH}$ values.

Figure 4c shows that there was an interaction between $\mathrm{Fe}(\mathrm{VI})$ dose and initial dye concentration. COD removal efficiency was decreased, while Fe (VI) dose increased. Also, middle value of initial concentration showed high efficiency on COD removal.

\subsection{Optimization Step}

According to the Design Expert version 8.0.4.1 software, the desired goal for each condition $(\mathrm{pH}, \mathrm{Fe}$ (VI) dose and initial dye concentration) was chosen as "in range". The programme found 27 solutions, which help to achieve optimum conditions for color and COD removal with high desirability range of $0.943-1$. The maximum predicted color and COD removal was $102 \%$ and $100 \%$, respectively. The ranges of optimum operational conditions for each parameter were: 4.087.69 for $\mathrm{pH}, 24-119.17 \mathrm{mg} / \mathrm{L}$ for $\mathrm{Fe}(\mathrm{VI})$ dose and $60.68-99.13 \mathrm{mg} / \mathrm{L}$ for initial dye concentration. On the other part, the desirability function approach was used to maximize both color and COD removal. Initial dye concentration was fixed to the middle value $(60 \mathrm{mg} / \mathrm{L})$ to achieve such a goal. The overlay plot for the optimal region is shown in Figure $\mathbf{5}$. The yellow portion gave the allowable values of the two variables ( $\mathrm{Fe}(\mathrm{VI})$ dose and $\mathrm{pH}$ ) by maximizing removal efficiencies of color and COD. According to Figure $\mathbf{5}$, if the process was conducted at $\mathrm{pH}$ range of 4.52-7.69 and $\mathrm{Fe}(\mathrm{VI})$ dose range of $79.55-119.17 \mathrm{mg} / \mathrm{L}$, both color and COD removal would be maximized for initial dye concentration of $60 \mathrm{mg} / \mathrm{L}$. Also, the calculated values for the validation experiments were found to be satisfactory (see Table $\mathbf{S} 2$ in supplementary material).

\section{CONCLUSIONS}

Response surface methodology (RSM) is a simple way for the optimization of the parameters for dye removal from textile waste water. RSM reduces the number of experiments. Besides, RSM provides important information about interactions between operational parameters. In this study, the model employed provided high accuracy with high $\mathrm{R}^{2}$ values ( 0.91 for color removal and 0.9813 for COD removal). Electrochemically produced ferrate (VI) was very effective for IC dye removal in terms of color and COD removal.

\section{ACKNOWLEDGEMENT}

This study was supported by Gebze Technical University in the frameworks of the project no: 2013A21. 


\section{SUPPLEMENTARY MATERIALS}

The supplementary materials can be downloaded from the journal website along with the article.

\section{REFERENCES}

[1] Van der Bruggen B, Curcio E, Drioli E. Process intensification in the textile industry: the role of membrane technology. J Environ Manage 2004; 73(3): 267-74. https://doi.org/10.1016/j.jenvman.2004.07.007

[2] Secula MS, Crețescu I, Petrescu S. An experimental study of indigo carmine removal from aqueous solution by electrocoagulation. Desalination 2011; 277(1): 227-35. https://doi.org/10.1016/j.desal.2011.04.031

[3] Jenkins CL. Textile dyes are potential hazards. J Environ Health 1978; 40(5): 256-63.

[4] Prado AG, Torres JD, Faria EA, Dias SIC. Comparative adsorption studies of indigo carmine dye on chitin and chitosan. J Colloid Interface Sci 2004; 277(1): 43-7. https://doi.org/10.1016/j.jcis.2004.04.056

[5] Mittal A, Kurup L, Mittal J. Freundlich and Langmuir adsorption isotherms and kinetics for the removal of Tartrazine from aqueous solutions using hen feathers. J Hazard Mater 2007; 146(1): 243-8. https://doi.org/10.1016/j.jhazmat.2006.12.012

[6] Cestari AR, Vieira EF, Tavares AM, Bruns RE. The removal of the indigo carmine dye from aqueous solutions using cross-linked chitosan-Evaluation of adsorption thermodynamics using a full factorial design. J Hazard Mater 2008; 153(1): 566-74.

https://doi.org/10.1016/j.jhazmat.2007.08.092

[7] Lakshmi UR, Srivastava VC, Mall ID, Lataye DH. Rice husk ash as an effective adsorbent: evaluation of adsorptive characteristics for Indigo Carmine dye. J Environ Manage 2009; 90(2): 710-20.

https://doi.org/10.1016/j.jenvman.2008.01.002

[8] Kesraoui A, Selmi T, Seffen M, Brouers F. Influence of alternating current on the adsorption of indigo carmine. Environ Sci Pollut Res 2016: 1-11

[9] Khelifi E, Gannoun H, Touhami Y, Bouallagui H, Hamdi M. Aerobic decolourization of the indigo dye-containing textile wastewater using continuous combined bioreactors. J Hazard Mater 2008; 152(2): 683-9. https://doi.org/10.1016/j.jhazmat.2007.07.059

[10] Sanroman M, Pazos M, Ricart M, Cameselle C. Decolourisation of textile indigo dye by DC electric current. Eng Geo 2005; 77(3): 253-61.

https://doi.org/10.1016/j.enggeo.2004.07.016

[11] Butrón E, Juárez ME, Solis M, Teutli M, González I, Nava JL. Electrochemical incineration of indigo textile dye in filterpress-type FM01-LC electrochemical cell using BDD electrodes. Electrochim Acta 2007; 52(24): 6888-94. https://doi.org/10.1016/j.electacta.2007.04.108

[12] Palma-Goyes RE, Silva-Agredo J, González I, Torres-Palma RA. Comparative degradation of indigo carmine by electrochemical oxidation and advanced oxidation processes. Electrochim Acta 2014; 140: 427-33. https://doi.org/10.1016/j.electacta.2014.06.096

[13] Subramani A, Byrappa K, Ananda S, Rai KL, Ranganathaiah $\mathrm{C}$, Yoshimura M. Photocatalytic degradation of indigo carmine dye using $\mathrm{TiO}_{2}$ impregnated activated carbon. Bull Mater Sci 2007; 30(1): 37-41. https://doi.org/10.1007/s12034-007-0007-8

[14] Barka N, Assabbane A, Nounah A, Ichou YA. Photocatalytic degradation of indigo carmine in aqueous solution by $\mathrm{TiO}_{2}$ coated non-woven fibres. J Hazard Mater 2008; 152(3): 1054-9.

https://doi.org/10.1016/j.jhazmat.2007.07.080
[15]

Torrades F, Saiz S, García-Hortal JA. Using central composite experimental design to optimize the degradation of black liquor by Fenton reagent. Desalination 2011; 268(1): 97-102.

https://doi.org/10.1016/j.desal.2010.10.003

[16] Khataee AR, Zarei M, Moradkhannejhad L. Application of response surface methodology for optimization of azo dye removal by oxalate catalyzed photoelectro-Fenton process using carbon nanotube-PTFE cathode. Desalination 2010; 258(1): 112-9. https://doi.org/10.1016/j.desal.2010.03.028

[17] Khataee A, Zarei M, Fathinia M, Jafari MK. Photocatalytic degradation of an anthraquinone dye on immobilized TiO 2 nanoparticles in a rectangular reactor: Destruction pathway and response surface approach. Desalination 2011; 268(1): 126-33. https://doi.org/10.1016/j.desal.2010.10.008

[18] Gómez-Solís C, Juárez-Ramírez I, Moctezuma E, TorresMartínez LM. Photodegradation of indigo carmine and methylene blue dyes in aqueous solution by $\mathrm{SiC}-\mathrm{TiO} 2$ catalysts prepared by sol-gel. J Hazard Mater2012; 217: 194-9.

https://doi.org/10.1016/j.jhazmat.2012.03.019

[19] Sood S, Kumar S, Umar A, Kaur A, Mehta SK, Kansal SK. $\mathrm{TiO} 2$ quantum dots for the photocatalytic degradation of indigo carmine dye. J Alloys Compd 2015; 650: 193-8. https://doi.org/10.1016/j.jallcom.2015.07.164

[20] Yao Y, Cui L, Li Y, Yu N, Dong $\mathrm{H}$, Chen $\mathrm{X}$, et al. Electrocatalytic Degradation of Methyl Orange on PbO2-TiO2 Nanocomposite Electrodes. Int J Environ Res 2015; 9(4): 1357-64.

[21] Naciri N, Farahi A, Rafqah S, Nasrellah H, El Mhammedi MA Lançar I, et al. Effective photocatalytic decolorization of indigo carmine dye in Moroccan natural phosphate-TiO2 aqueous suspensions. Opt Mater 2016; 52: 38-43. https://doi.org/10.1016/j.optmat.2015.12.011

[22] Tünay $O$, Şimşeker $M$, Kabdaşlı I, Ölmez-Hancı $T$. Abatements of reduced sulphur compounds, colour, and organic matter from indigo dyeing effluents by electrocoagulation. Environ Technol 2014; 35(13): 1577-88. https://doi.org/10.1080/09593330.2013.873824

[23] Barışçı S, Turkay O, Dimoglo A. Review on Greywater Treatment and Dye Removal from Aqueous Solution by Ferrate (VI). Ferrites and Ferrates: Chemistry and Applications in Sustainable Energy and Environmental Remediation: ACS Publications 2016; pp. 349-409.

[24] Sun X, Zhang Q, Liang H, Ying L, Xiangxu M, Sharma VK. Ferrate $(\mathrm{VI})$ as a greener oxidant: Electrochemical generation and treatment of phenol. J Hazard Mater 2016; 319: 130-6. https://doi.org/10.1016/j.jhazmat.2015.12.020

[25] Nam J-H, Kim I-K, Kwon J, Kim YD. Applications of electrochemical ferrate (VI) for degradation of trichloroethylene in the aqueous phase. Desalin Water Treat 2016; 57(11): 5138-45. https://doi.org/10.1080/19443994.2014.1001440

[26] Barışçı S, Ulu F, Sillanpää M, Dimoglo A. Evaluation of flurbiprofen removal from aqueous solution by electrosynthesized ferrate (VI) ion and electrocoagulation process. Chem Eng J 2015; 262: 1218-25. https://doi.org/10.1016/j.cej.2014.10.083

[27] Sun X, Zhang Q, Liang H, Ying L, Xiangxu M, Sharma VK. Ferrate $(\mathrm{VI})$ as a greener oxidant: Electrochemical generation and treatment of phenol. J Hazard Mater 2015.

[28] Zhou Z, Jiang J-Q. Treatment of selected pharmaceuticals by ferrate (VI): Performance, kinetic studies and identification of oxidation products. J Pharm Biomed Anal 2015; 106: 37-45 https://doi.org/10.1016/j.jpba.2014.06.032

[29] Jiang J-Q, Zhou Z, Patibandla S, Shu X. Pharmaceutical removal from wastewater by ferrate $(\mathrm{VI})$ and preliminary 
effluent toxicity assessments by the zebrafish embryo model. Microchem J 2013; 110: 239-45 https://doi.org/10.1016/j.microc.2013.04.002

[30] Manoli K, Nakhla G, Ray AK, Sharma VK. Enhanced oxidative transformation of organic contaminants by activation of ferrate (VI): Possible involvement of Fe V/Fe IV species. Chem Eng J 2017; 307: 513-7. https://doi.org/10.1016/j.cej.2016.08.109

[31] Tomic M, Bujanovic LN, Cekerevac M, Zdravkovic $M$. Application of electrochemically synthesized ferrate $(\mathrm{Vi})$ in the treatment of phenol contaminated wastewater from wood industry. Acta Tech Corviniensis-Bull Eng 2017; 10(1): 39.

[32] Turkay O, Barışçı S, Dimoglo A. Kinetics and mechanism of methylene blue removal by electrosynthesized ferrate (VI). Sep Sci Technol 2016; 51(11): 1924-31. https://doi.org/10.1080/01496395.2016.1182189

[33] Myers RH, Montgomery DC, Anderson-Cook CM. Response surface methodology: process and product optimization using designed experiments: John Wiley \& Sons 2009.

[34] Bezerra MA, Santelli RE, Oliveira EP, Villar LS, Escaleira LA. Response surface methodology (RSM) as a tool for optimization in analytical chemistry. Talanta 2008; 76(5): 965-77. https://doi.org/10.1016/j.talanta.2008.05.019

[35] Baş D, Boyacı ì Modeling and optimization I: Usability of response surface methodology. J Food Eng 2007; 78(3): 836-45. https://doi.org/10.1016/j.jfoodeng.2005.11.024

[36] Sohail Y, Parag B, Nemeshwaree B, Giorgio R. Optimizing Organophosphorus Fire Resistant Finish for Cotton Fabric
Using Box-Behnken Design. Int J Environ Res 2016; 10(2): 313-20.

[37] Domínguez JnR, González T, Palo $P$, Sánchez-Martín J. Electrochemical advanced oxidation of carbamazepine on boron-doped diamond anodes. Influence of operating variables. Ind Eng Chem Res 2010; 49(18): 8353-9.

[38] Benatti CT, Tavares CRG, Guedes TA. Optimization of Fenton's oxidation of chemical laboratory wastewaters using the response surface methodology. J Environ Manage 2006; 80(1): 66-74.

https://doi.org/10.1016/j.jenvman.2005.08.014

[39] Arslan-Alaton I, Yalabik AB, Olmez-Hanci T. Development of experimental design models to predict Photo-Fenton oxidation of a commercially important naphthalene sulfonate and its organic carbon content. Chem Eng J 2010; 165(2): 597-606.

https://doi.org/10.1016/j.cej.2010.10.003

[40] Vepsäläinen M, Ghiasvand M, Selin J, Pienimaa J, Repo E, Pulliainen $\mathrm{M}$, et al. Investigations of the effects of temperature and initial sample $\mathrm{pH}$ on natural organic matter (NOM) removal with electrocoagulation using response surface method (RSM). Sep Purif Technol 2009; 69(3): 25561.

https://doi.org/10.1016/j.seppur.2009.08.001

[41] Barışçı S, Ulu F, Sarkka H, Dimoglo A, Sillanpaa M. Electrosynthesis of Ferrate (VI) ion Using High Purity Iron Electrodes: Optimization of Influencing Parameters on the Process and Investigating Its Stability. Int J Electrochem Sci 2014; 9(6): 3099-107. 